\title{
STUDIES ON THE ANATOMY OF INDIAN MOLLUSCA.
}

\author{
1. THE MARSUPIUM AND GLOCHIDIUM OF THE \\ GENUS PHYSUNIO.
}

\author{
By Batni Prashad, M.Sc., Superintendent of Fisheries, \\ Bengal Fisheries Laboratory, Indian Museum, Calcutta.
}

(Plate XXII).

On the occasion of a tour in the Southern Shan States Dr. N. Annandale and Dr. F. H. Gravely collected specimens of two new species of the genus Physunio, Simpson. These are the only two Unionidae found in the basin of the Inle Lake, where the specimens were collected. $P$. ferrugineus is a true lacustrine form and is found in the middle of the lake in very clear water, whilst the other species ( $P$. micropteroides) is found in a muddy stream opening into the lake.

Dr. Annandale was kind enough to give me specimens of both the forms in order that I might describe their glochidia. Whilst working out the structure of these, it was found that the marsupium of the genus was peculiar, and an account of this structure is also included here. At Dr. Annandale's suggestion I looked through the large collection of fishes made at the same locality, and I was fortunate enough to find specimens with glochidia attached to their fins.

My sincere thanks are due to Dr. Annandale for giving me the opportunity of making this very interesting study, and for kind help at all times. I am also highly obliged to Mr. T. Southwell, A.R.C.S., F.Z.S., Director of Fisheries, Bengal and Bihar and Orissa, for kindly allowing me to undertake and publish this work.

Marsupium.-By the term marsupium in the description of the freshwater mussels, we mean those portions of the gills in which the eggs are received from the supra-branchial chambers after ovulation and which serve as brood-pouches for the retention and nurture of the embryos and glochidia until the latter are shed. As different portions of the gills are specialized in the various groups of Unionidae to serve as a marsupium and as this has been found to be a constant character, the marsupium has been used as the chief diagnostic character of these groups. Simpson (4) divided the Unionidae according to this character into Exobranchiae, with the marsupium comprising the outer gill on each side or all four gills, and the Endobranchiae, in which the inner pair of gills alone serve as the brood-pouch. In the genus Physunio nothing was known about the anatomy of the animal, but Simpson, judging from the shell-characters alone, was led to include it amongst the Endobranchiae. This was an entirely wrong conclusion. Gravid females were found in both the two new species collected and described by Dr. Annandale, and it is to this fortunate chance that I owe the description of the marsupium and the glochidium of the genus. No attempt is made to describe the histological or anatomical structure of the gills in the present account as the anatomy of the animal is being described in detail by Dr. Ekendranath Ghosh. 
In both the species only the middle region of the outer gills is specialized to serve as a marsupium, while a larger posterior and a much smaller anterior portion retain the ordinary respiratory character. The marsupial region in both species is much swollen and in the preserved specimens is of a creamy colour. It is clearly marked off from the anterior and posterior respiratory regions. In $P$. micropteroides seventeen water-tubes are modified to serve as a brood-pouch, while in P. ferrugineus only eleven are thus modified.

The characters of the marsupium of the genus may be summed up as follows. Marsupium formed by 11-17 simple water-tubes in the middle region of the outer gills, leaving a larger posterior and a much smaller anterior unmodified portion for respiration.

From these characters it will be seen that Physunio should be included in the group Exobranchiae of Simpson, and comes into his sub-group Mesogenae. He established this sub-group to include the genera Cyproyenia and Obliquaria, in both of which a variable number (7-23) of tubes in the middle region of the outer gills are specialized as the marsupium, a larger anterior and a shorter posterior region remaining respiratory. The marsupium of Physunio agrees with the above two genera in having the middle region of the outer gills modified, but differs in that the shorter respiratory portion of the gills is anterior and not posterior as in the American forms ; also the modified water-tubes are in no way specially elongated. Ortmann (3) as a result of his anatomical researches has found it necessary to combine Simpson's sub-groups Heterogenae, Mesogenae, Ptychogenae and presumably also the Eschatigenae into one group. In these forms various portions of the outer gills are modified as brood-pouches. Ortmann has included in the united group recognised without special name all the forms in which a differentiated portion only of the outer gills functions as the marsupium.

The genus Physunio must, therefore, also be included here and not amongst the Endobranchiae. The water-tubes (fig. 2) are filled with glochidia throughout their length, and in the fully charged marsupium the great antero-posterior distention of the water-tubes is very well marked; the inter-lamellar junctions also are much elongated in this region. The glochidia were seen to be rather loosely attached to one another by their larval membranes and could easily be shaken apart.

Glochidium.-The glochidia of the two species differ mainly in size. In the case of $P$. micropteroides (fig. 3) a glochidium measures $0.32 \mathrm{~mm}$. by $0.29 \mathrm{~mm}$., while that of $P$. ferrugineus (fig. 10) is much smaller, being $0.28 \mathrm{~mm}$. by $0.26 \mathrm{~mm}$. The glochidium of $P$. micropteroides is described here in detail.

The glocidium is of the hookless types. It has the usual two shell valves. As seen in lateral view the shell is semi-circular with a curved lower margin and an upper hinge-line. This line is nearly straight in $P$. ferrugineus, a little curved in $P$. micropteroides. The shell is thin in the middle and all over except along the hinge-line and the border, where it shows a distinct thickening. The whole surface, except the border, is finely granulated. From the inner edge of the ventral border (figs. 4 and 5) a continuous flange projects inwards; seen from the anterior or posterior side this flange appears as a pointed tooth, but it is a con- 
tinuous structure all along the margin. It shows very fine ridges on its ventral surface. Amongst the hookless glochidia like the present example this flange must serve the same purpose as the tooth in the hooked glochidia though perhaps in a less efficient manner. Between the two valves of the shells a ligament is present and can be easily distinguished in sections and stained preparations.

The inside of the shell valves is lined by the larval mantle (figs. 6 and 7 ), which is formed of large cells. The cells have a conspicuous nucleus and the cytoplasm is filled with a large number of minute granules. In the mantle flap of each side two pairs of sensory cells (s.c.) can be distinguished, one lying below the other. The adductor muscle (a. $m$. figs. 9 and 6 ), which is seen as a whitish nearly circular area through the shell in lateral view, lies near the anterior and dorsal margins of the shell. The muscle consists of muscle-fibres stretching from one valve to the other; these fibres have elongated unclei and are seen to divide before becoming attached to the valves. Lying just posterior and at a little higher level than the adductor muscle is a triangular area (an. figs. 3 and 7). This is the rudiment of the various organs of the future adult mollusc. It consists of closely packed cells and extends a little below the posterior margin of the adductor muscle.

Fish host.-It is a well-known fact that after being shed from the marsupium, the glochidia, whether of the hooked or hookless type, become attached to the gills or the fins of fishes and that each species usually affects a single host or a group of closely allied hosts.

The glochidia in the present case were seen attached to the caudal fins of three species of fishes. The specific characters of the larvae can be easily distinguished and hence the infection of the fish appears to have occurred recently. The specimens were obtained at the end of February and the beginning of March. The glochidia of $P$. micorpteroides were found on the caudal fins of Nemachilus brunneanus (fig. 8) and Nemachilus brevis (fig. 9) ; both these species of fish were taken in streams. A single glochidium of $P$. ferrugineus was found, on the other hand, deeply embedded in the caudal fin of Baritius auropurpureus (fig. 11). The two species of Nemachilus are found among weeds near or at the bottom and the Baritius, though it usually swims near the surface, goes down to the bottom at mid-day and was observed searching for insect larvae, etc., in the mud at places at which $P$. ferrugineus was abundant.

\section{LITERATURE.}

1. Lefevre, G., and Curtis, W. C.- "Studies on the Reproduction and propagation of fresh-water mussels." Bulletin of the Bureau of Fisheries, Washington, Vol. XXX, 1912.

2. Lillie, F. R.- "The Embryology of Unionidae." Journal of Morphology, Vol. X, 1895.

3. Ortmann, A. E.-."A monograph of the Najades of Pennsylvania." Memoirs of the Carneyie Museum, Pittsburgh, Vol. IV, 1911.

4. Simpson, C. T.- "Synopsis of the Naiades or pearly fresh-water Mussels." Proceedings of the United States National Museum, Vol. XXII, 1900. 


\section{EXPLANATION OF PLATE XXII.}

FIg. 1.-Gravid female of Physunio micropieroides. $M .=$ marsupium.

FIf. 2.--Horizontal longitudinal section of a water-tube of gravid marsupium showing the glochidia in the water-tube $(u . t$.$) .$

FIG. 3.-Lateral view of a glochidiuni. a.m.=adductor muscle; $a n$. =anlagen.

FIG. 4.-Anterior end view of the glochidium. S.c. $=$ sensory cells.

Fig. 5.-Glochidium after removal of one of the shells. A. m.=adductor muscle ; $a n .=$ anlagen $; f=$ flange.

FIG. 6.-Transverse section of a glochidium through the region of the adductor muscle $(a . m$.$) . M .=$ mantle.

FIG. 7.- Transverse section of a glochidium through the anlagen (an.) of the various organs.

FIG. 8.-Glochidium on the edge of the caudal fin of Nemachitus brunneanus.

FIG. 9.--Glochidium on the caudal fin. of $N$. brevis.

FIG. 10.-Lateral view of a glochidium of $P$. ferrugineus.

FIc. 11.-A glochidium of $P$. ferrugineus embedded in the caudal fin of Barilius auropurpureus.

Figures 2-9 are from specimens of $P$. micropteroides. 

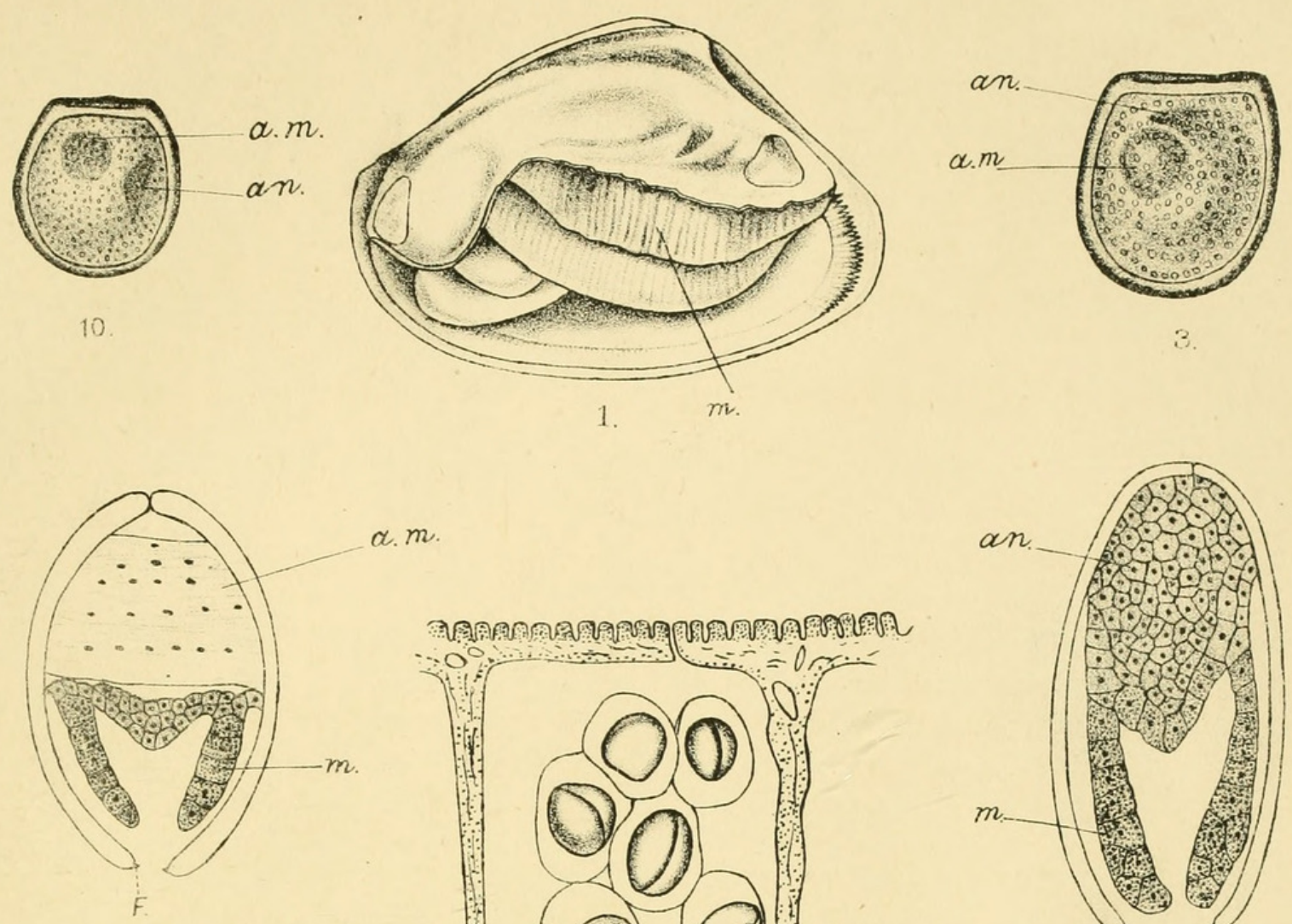

a. $m$.
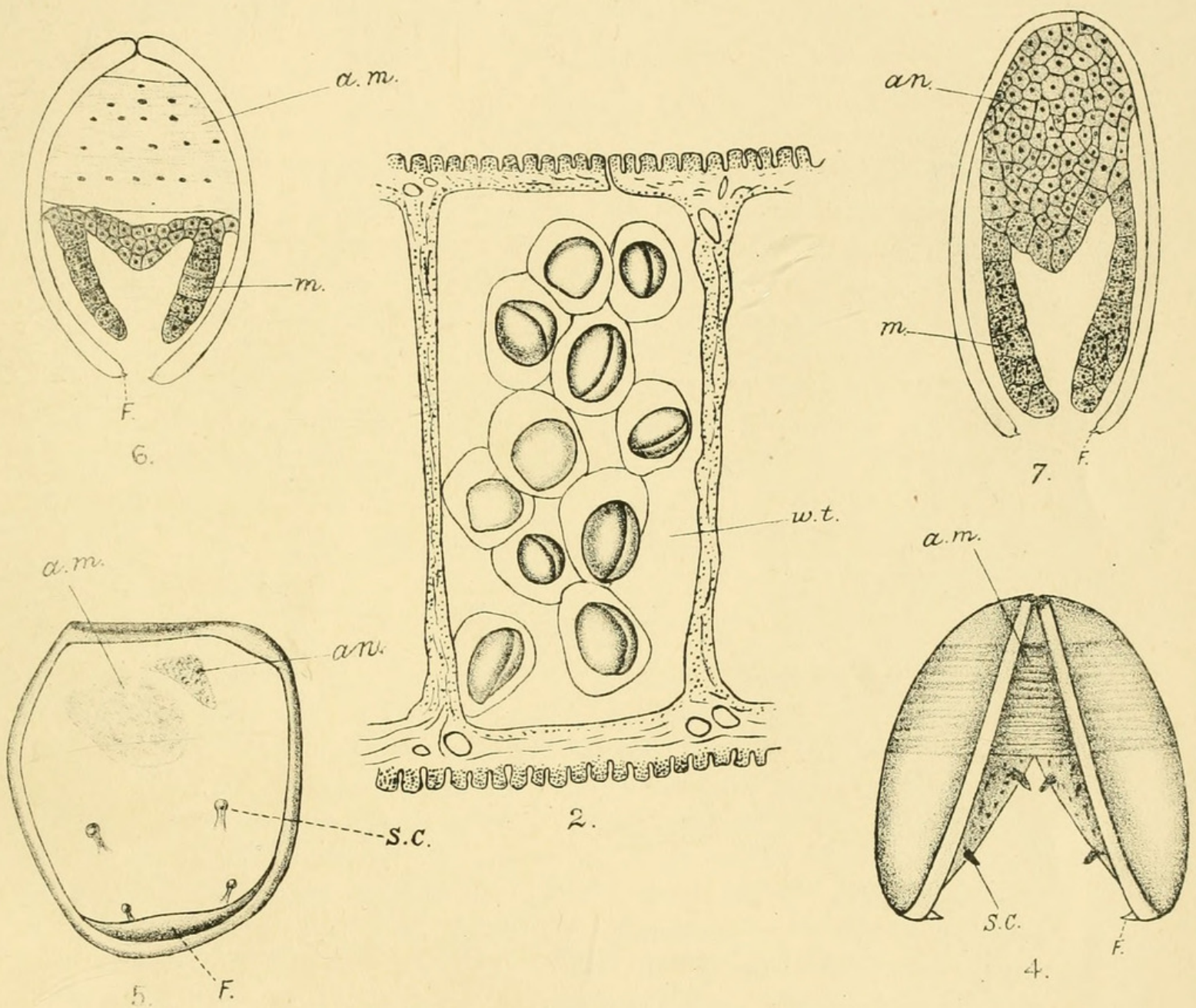

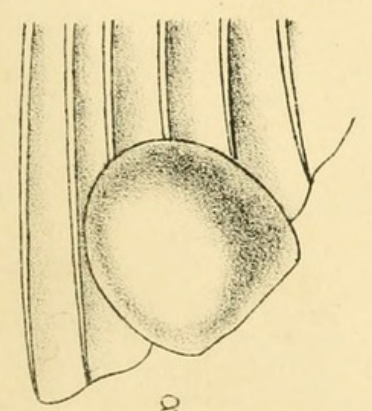

8

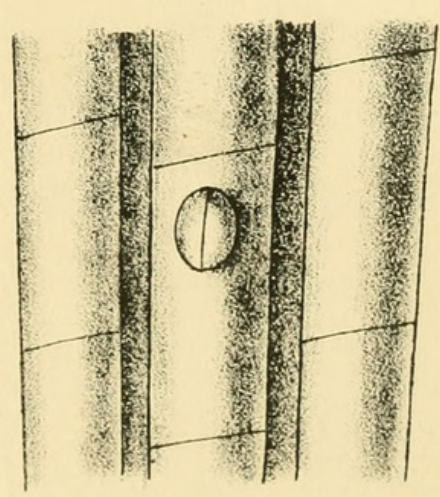

11

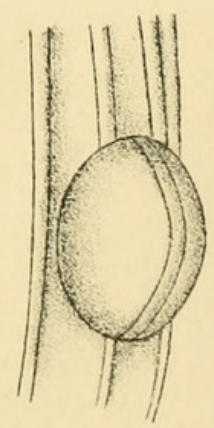

9.

B. Prashad,

S.C.Mondul lith.

\&.S.C.Mondul del. 


\section{$2 \mathrm{BHL}$ Biodiversity Heritage Library}

1918. "Studies on the anatomy of Indian mollusca. 1. The marsupium and glochidium of the genus Physunio." Records of the Indian Museum 14, 183-187. https://doi.org/10.5962/bhl.part.18608.

View This Item Online: https://www.biodiversitylibrary.org/item/41767

DOI: https://doi.org/10.5962/bhl.part.18608

Permalink: https://www.biodiversitylibrary.org/partpdf/18608

\section{Holding Institution}

MBLWHOI Library

\section{Sponsored by}

MBLWHOI Library

\section{Copyright \& Reuse}

Copyright Status: Public domain. The BHL considers that this work is no longer under copyright protection.

This document was created from content at the Biodiversity Heritage Library, the world's largest open access digital library for biodiversity literature and archives. Visit BHL at https://www.biodiversitylibrary.org. 